Original paper

\title{
MINERAL COMPOSITION OF SELECTED SERBIAN PROPOLIS SAMPLES
}

\author{
Snezana Tosic*1 \\ Gordana Stojanovic ${ }^{1}$ \\ Snezana Mitic ${ }^{1}$ \\ Aleksandra Pavlovic ${ }^{1}$ \\ Sladjana Alagic ${ }^{2}$ \\ ${ }^{1}$ Department of Chemistry, Faculty of Sciences and Mathematics, University of Niš, \\ Serbia \\ 2 Technical Faculty Bor, University of Belgrade, Serbia \\ *corresponding author: sneskat@yahoo.com \\ Received: 9 April 2015; accepted: 30 December 2016
}

A bstract

The aim of this work was to determine the content of 22 macro- and microelements in ten raw Serbian propolis samples which differ in geographical and botanical origin as well as in polluted agent contents by atomic emission spectrometry with inductively coupled plasma (ICP-OES). The macroelements were more common and present Ca content was the highest while Na content the lowest. Among the studied essential trace elements Fe was the most common element. The levels of toxic elements ( $\mathrm{Pb}, \mathrm{Cd}, \mathrm{As}$ and $\mathrm{Hg}$ ) were also analyzed, since they were possible environmental contaminants that could be transferred into propolis products for human consumption. As and $\mathrm{Hg}$ were not detected in any of the analyzed samples but a high level of $\mathrm{Pb}(2.0-9.7 \mathrm{mg} / \mathrm{kg})$ was detected and only selected portions of raw propolis could be used to produce natural medicines and dietary supplements for humans. Obtained results were statistically analyzed, and the examined samples showed a wide range of element content.

Keywords: bioindicator, elements propolis, ICP-OES determination,

\section{INTRODUCTION}

Propolis is a resinous substance that bees collect from plants. The word originates from Greek meaning "in front of the city" ( pro-in front, poliscity), which suits the protecting role of propolis for a bee colony (Bogdanov, 2014). Propolis has antioxidant, antibacterial, antiseptic, antitumor, antiinflammatory, anesthetic and antivirus properties. It is usually sold in the form of alcoholic tinctures, tablets, capsules, syrups or sprays. Bee products are often used as nutritional supplements. Propolis has been proposed as a germicide in food packaging or as a chemical preservative in some food products (Tosi et al., 2007). It is usually consumed as an extract, whose composition of bio-active components can consist of phenolic compounds, flavonoids, amino acids. The content of essential metals, toxic metals and pesticides, depending on the following: type of solvent - different percentages of ethanol, pure water, edible oils; extraction procedures - Soxhlet extractor, turbo-extraction, supercritical extraction with $\mathrm{CO}_{2}$ of dried ethanolic extract surfactants; subsequent cryogenic filtration of propolis extract; and extraction times etc. Studies have shown that although the concentration of such heavy metals as lead in the crude samples exceeded the maximum permitted for food, most remained in the insoluble residue after ethanol extraction, so the ethanolic extracts were practically lead-free (Cunha et al., 1997; Sawaya, Cunha \& Marcucci, 2011).

The presence of minerals, which are a natural part of terrestrial systems occurring in soil, rock, air, water and also organisms, can significantly affect the pharmacotherapeutic properties of derived products. Because some of them are essential and propolis is used as a dietary supplement, it is important to know its mineral content. The roles of macroelements are well known. Calcium (Ca) provides the formation of bones and the growth of strong teeth, muscle 
contraction, transmission of nerve signals and secretion of hormones and enzymes. Magnesium (Mg) is important for the proper functioning of the heart, muscles, kidneys, and the building of teeth, bones and enzyme systems. Potassium (K) ensures membrane transport, energy metabolism, normal cell functioning, cardiac contraction and proper functioning of the intestines and muscles. Sodium (Na) is involved in blood circulation and the maintenance of blood pressure and total quantity of normal blood levels. Phosphorus ( $P$ ) plays an important role in the production of collagen and is an integral part of phospholipids which are located within the cell membrane and the main component of adenosine triphosphate, which provides energy for cells.

The trace elements are as follows. Iron (Fe) is an integral part of the heme in hemoglobin, participates in DNA synthesis and catecholamine metabolism and serves as a carrier of electrons in the mitochondrial. Zinc (Zn), a component of thousands of proteins, is important for the control and harmonization of the nervous system and hormones, defence of the organism and maintenance of the structure and health of skin and bone tissue regeneration. Copper (Cu) is a component of blood and an integral part of many enzymes. Manganese (Mn), an antioxidant, helps the body to use several important vitamins, including vitamin B1, biotin and vitamin C. Silicon (Si) participates in the structure of cell walls and is important as a component of several enzymes. Nickel ( $\mathrm{Ni})$ is a constituent of urease. Finally, boron (B) regulates metabolism, growth and development of bone tissue with calcium, magnesium and vitamin $\mathrm{D}$.

Environment pollution has increased due to the chemical, heavy and food industries, motorization development and intensive agriculture. Honey bee products can be contaminated by beekeeping practices with acaricides, antibiotics, bee repellents at honey harvest and pesticides or from the environment with heavy metals, radioactive isotopes, organic pollutants, pesticides, pathogenic bacteria and genetically modified organisms (Bogdanov, 2006). When the raw materials i.e. nectar, honeydew, pollen and plant exudates, are processed by bees, they are not purified and because of that contaminants from air, plants and soil can be transported into the bee hive. Honey bees, the brood and such bee products as honey, beeswax, propolis and royal jelly are good biological indicators of the chemical impairment of the environment. For biomonitoring purposes, a suitable method of analysis could determine the presence of pesticides and their residues, heavy metals and radionuclides and organic pollutants in these types of environmental samples. Heavy metals are emitted by various natural and anthropic sources, and because they are not biodegradable, they enter in the physical and biological cycles. Atmospheric heavy metals can deposit on the hairy bodies of bees and be brought to the hive along with pollen or be absorbed with flower nectar, water or honeydew. Rain and wind, nectar flow and the botanical origin of bee products are the main variables which influence the content of heavy metals (Porini et al., 2002). Propolis is much more contaminated with heavy metals than any other bee products. Measurements of heavy metals in bees, especially dead, and honey bee products may be considered as useful parameters and suitable tools in the monitoring of environmental contaminants (Leita et al., 1996). Honey bees have great mobility and a wide flying range and sampling the entire environment (soil, water, air, plants), requires a vast area to be monitored. While bee mortality is a consequence of contamination by pesticides, chemical species such as metals cause latent and non-immediate toxicity and therefore involve direct measurements of bioaccumulation in the tissues of the bees and/or in their products (Conti \& Botre, 2001). Pollen and propolis are far less processed by bees than wax and honey and more precisely reflect environmental contamination (Formicki et al., 2013). Inductively coupled plasma optical emission spectrometry (ICP-OES) is a multi-element technique for the detection of major, minor and trace elements in different complex samples. It combines qualities such as relatively low detection limits and high capacity for the simultaneous and precise detection for short intervals 
over wide concentration ranges. The aim of this work was to determine the mineral content of ten raw propolis samples from different areas of Serbia using ICP-OES.

\section{MATERIAL AND METHODS}

\section{Reagents}

Ultra scientific (USA) ICP multi-element standard solution of about $20.00 \pm 0.10 \mathrm{mg} / \mathrm{L}$ was used as a stock solution for calibration. Nitric acid (Merck, Darmstadt, Germany) was used for complete mineralization of analyzed samples.

\section{Instrumentation}

The overall analysis was conducted with an iCAP 6000 inductively coupled plasma optical emission spectrometer (Thermo Scientific, Cambridge, UK) which combines an Echelle optical design and a charge injection device (CID) solid state detector. iTEVA operating software for the iCAP 6000 series was used to control

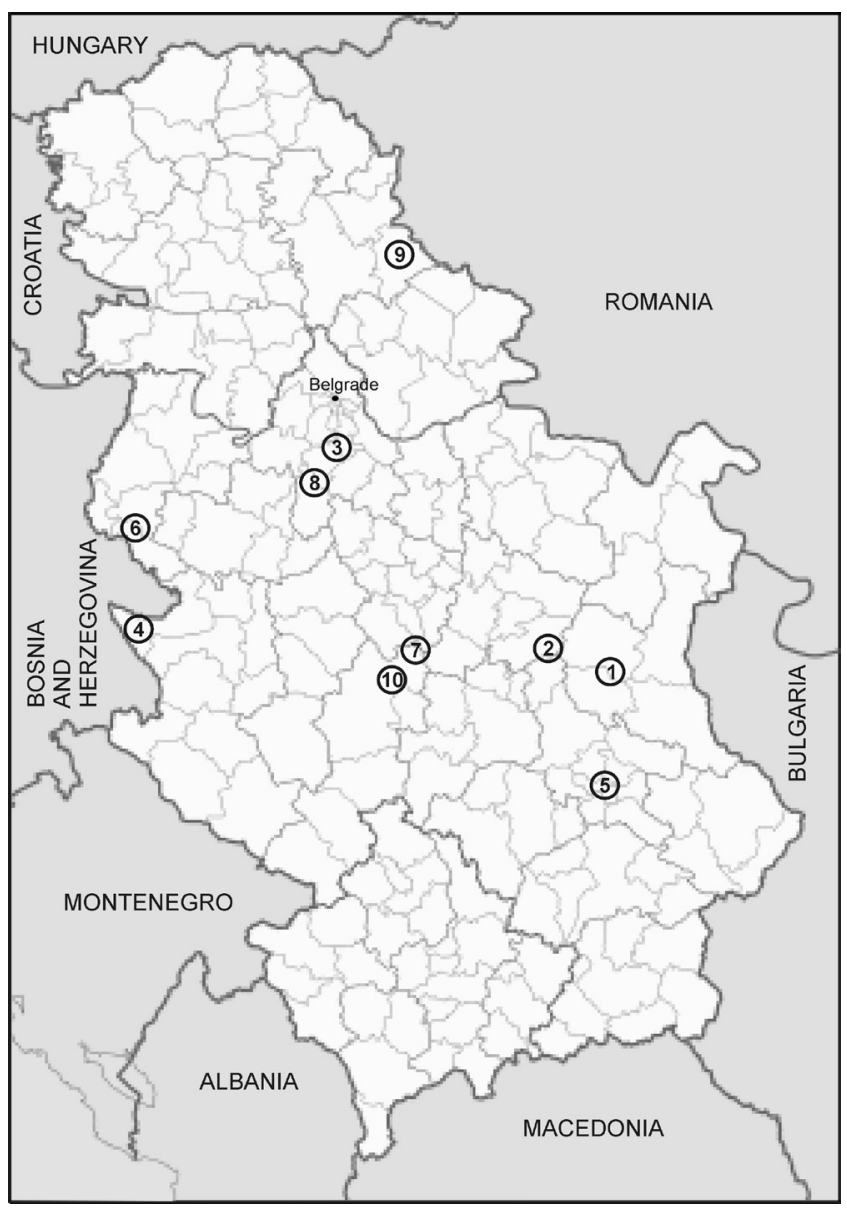

Fig. 1 The map of Serbia with marked locations of the analyzed propolis samples all the instrument's functions. Tab. 1 gives the optimal operating conditions for the instrument. Tab. 2 gives the selected emission lines for each of the elements, based on the tables of known interferences, baseline shifts and the background correction (the highest signal-to-background ratio), which was manually selected for the quantitative measurements. The validation process of the measurements based on the ICP-OES technique involved linearity of the calibration curve, detection and quantification limit (Tab. 2). Linearity was assessed with the correlation coefficients of calibration curves. Detection (LOD) and quantification (LOQ) limits were expressed as $L O D=3 \times S D / m$ and $L O Q=10 \times S D / m$, respectively. SD was the standard deviation of blank responses and $m$ the slope of the calibration graph. Mettler Toledo analytical balance (Switzerland) was used to measure the mass. High purity water (conductivity $0.05 \mu \mathrm{S} / \mathrm{cm}$ ) was obtained using the MicroMed high purity water system (Thermo Electron LED GmbH, Germany).

\section{Samples}

Samples of raw propolis were collected by scraping the frames of bee hives that originated from ten different regions of Serbia (Tab. 3 and Fig. 1) during 2013. The representative sample of a particular location was obtained through mixing the propolis from ten different apiaries. The samples were frozen and pulverized. Wet ashing of mineralization was used for the complete decomposition of the organic matrix. In this procedure, approximately $2 \mathrm{~g}$ of each raw sample of propolis were treated with 30 $\mathrm{mL}$ of concentrated $\mathrm{HNO}_{3}$ and heated on a hot plate up to $150^{\circ} \mathrm{C}$ until complete dissolution. The obtained solutions were filtered and diluted with deionized water up to $50 \mathrm{~mL}$ (Korn et al., 2008).

\section{Statistical analysis}

All measurements were carried out in triplicates and presented as mean \pm standard deviation (SD). The Pearson's correlation study, hierarchical cluster analysis and one-way analysis of variance (ANOVA) with Tukey's post-hoc test were done using a statistical package IBM SPSS 20, US. 


\section{RESULTS}

The minerals studied in this work were classified according to the criteria of the World Health Organization into the following groups: essential macroelements ( $\mathrm{Na}, \mathrm{Ca}, \mathrm{Mg}, \mathrm{K}$ and P) (Tab. 4), essential trace elements and trace elements that are probably essential (Fe, Zn, $\mathrm{Cu}, \mathrm{B}, \mathrm{Co}, \mathrm{Si}, \mathrm{Mn}, \mathrm{Ni}, \mathrm{Cr}$ and $\mathrm{Se}$ ) (Tab. 5) and toxic and potentially toxic - possibly with essential functions (Cd, Pb, Hg, As, Al, Li and Sn) (Tab. 6) (World Health Organisation, 1996). Analysis of variance was used to establish which metals significantly differed in the mean content between the analyzed samples.

In order to establish the possible correlations between the contents of the studied elements, the Pearson's correlation study was applied. Because of the importance of examination from the aspect of environmental pollution, the correlation coefficients for the most investigated heavy metals are given in Tab. 7.

The hierarchical agglomerative cluster analysis (CA) as a multivariate technique was also applied

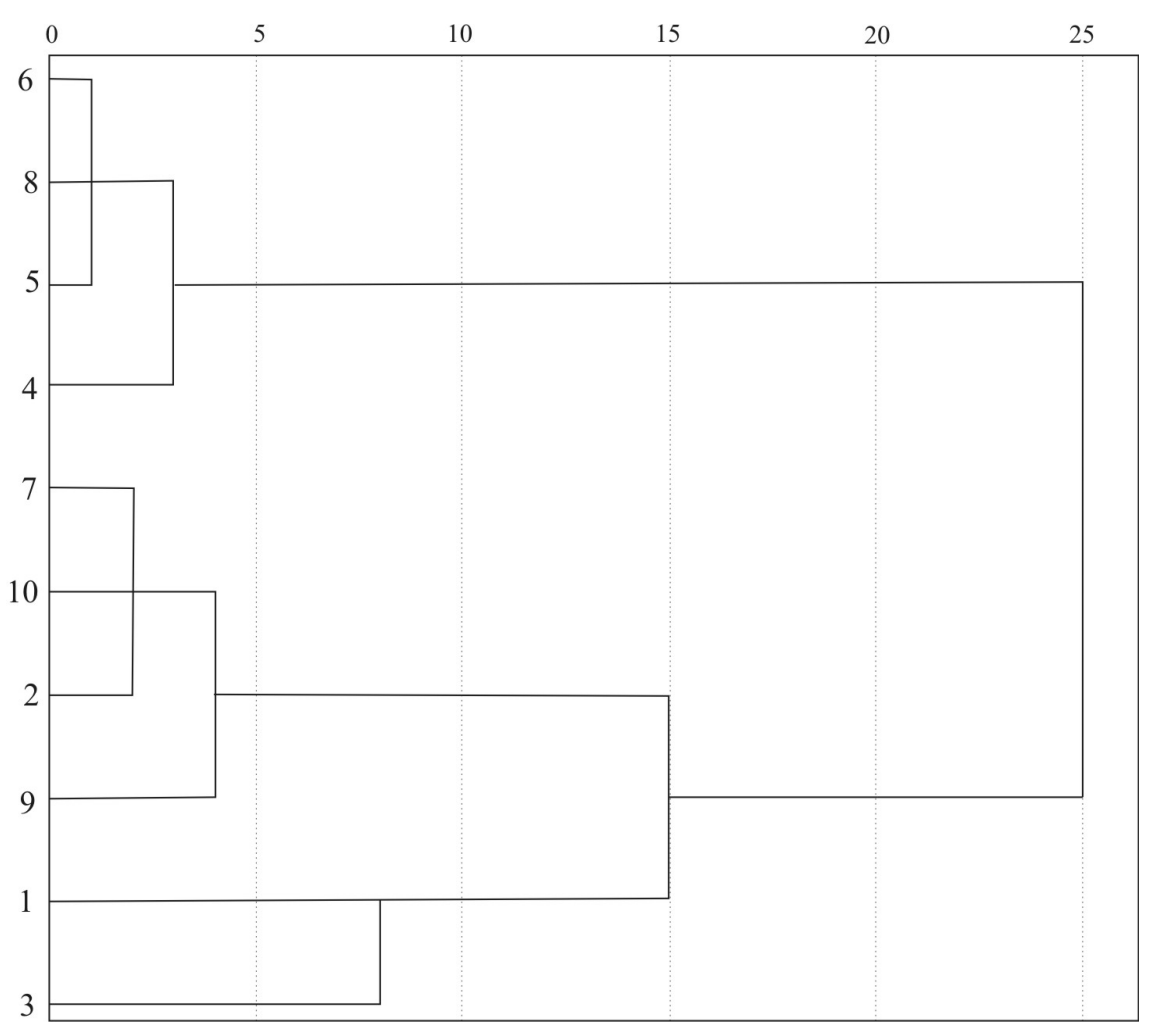

Fig. 2 Hierarchical dendrogram for investigated sites based on all metals' contents in raw propolis to the element concentrations in analyzed samples in order for them to be classified into categories or clusters based on their similarities. CA was performed on the normalized data set by means of the Ward's method using squared Euclidean distance. Cluster analysis was performed on both, based on the content of all investigated metals (Fig. 2) and those (Fig. 3) based on the content of heavy metals.

\section{DISCUSSION}

Because of many honeybee products applied in human nutrition despite being possibly contaminated with heavy metals, it was important to know the mineral composition of raw propolis samples. Based on the obtained results, the contents of macroelements were concluded to be the most common in the order of $\mathrm{Ca} /$ $\mathrm{K}>\mathrm{Mg} / \mathrm{P}>\mathrm{Na}$. This is in agreement with a study of element content of 25 raw propolis samples collected from different areas of southern Spain showed that among the analyzed metals, macroelements were found to be the most predominant in the same descending order. The content of Ca ranged from $1773 \mathrm{mg} /$ $\mathrm{kg}$ to $6683 \mathrm{mg} / \mathrm{kg}$; K from 735 $\mathrm{mg} / \mathrm{kg}$ to $4790 \mathrm{mg} / \mathrm{kg} ; \mathrm{Mg}$ from $301 \mathrm{mg} / \mathrm{kg}$ to $1364 \mathrm{mg} / \mathrm{kg} ; \mathrm{P}$ from $171 \mathrm{mg} / \mathrm{kg}$ to $611 \mathrm{mg} / \mathrm{kg}$ and $\mathrm{Na}$ from $93 \mathrm{mg} / \mathrm{kg}$ to 225 $\mathrm{mg} / \mathrm{kg}$ (Bonvehi \& Bermejo, 2013). Croatian propolis samples were found to have a similar order of $\mathrm{Ca}>\mathrm{Mg}>\mathrm{K}>\mathrm{Na}$ (Cvek et al., 2008). Formicki et al. (2013) found $137-823 \mathrm{mg}$ $\mathrm{Mg} / \mathrm{kg}$.

Among the studied essential trace elements, Fe was the most common and its content ranged from $116 \mathrm{mg} / \mathrm{kg}$ to 284 $\mathrm{mg} / \mathrm{kg}$. Some studies found similar values of 312-1270 $\mathrm{mg} / \mathrm{kg}$ (Bonvehi \& Bermejo, 2013), $162 \mathrm{mg} / \mathrm{kg}$ (Cantarelli et al., 2011) and 28-101 mg/kg (Formicki et al., 2013). Zn was 


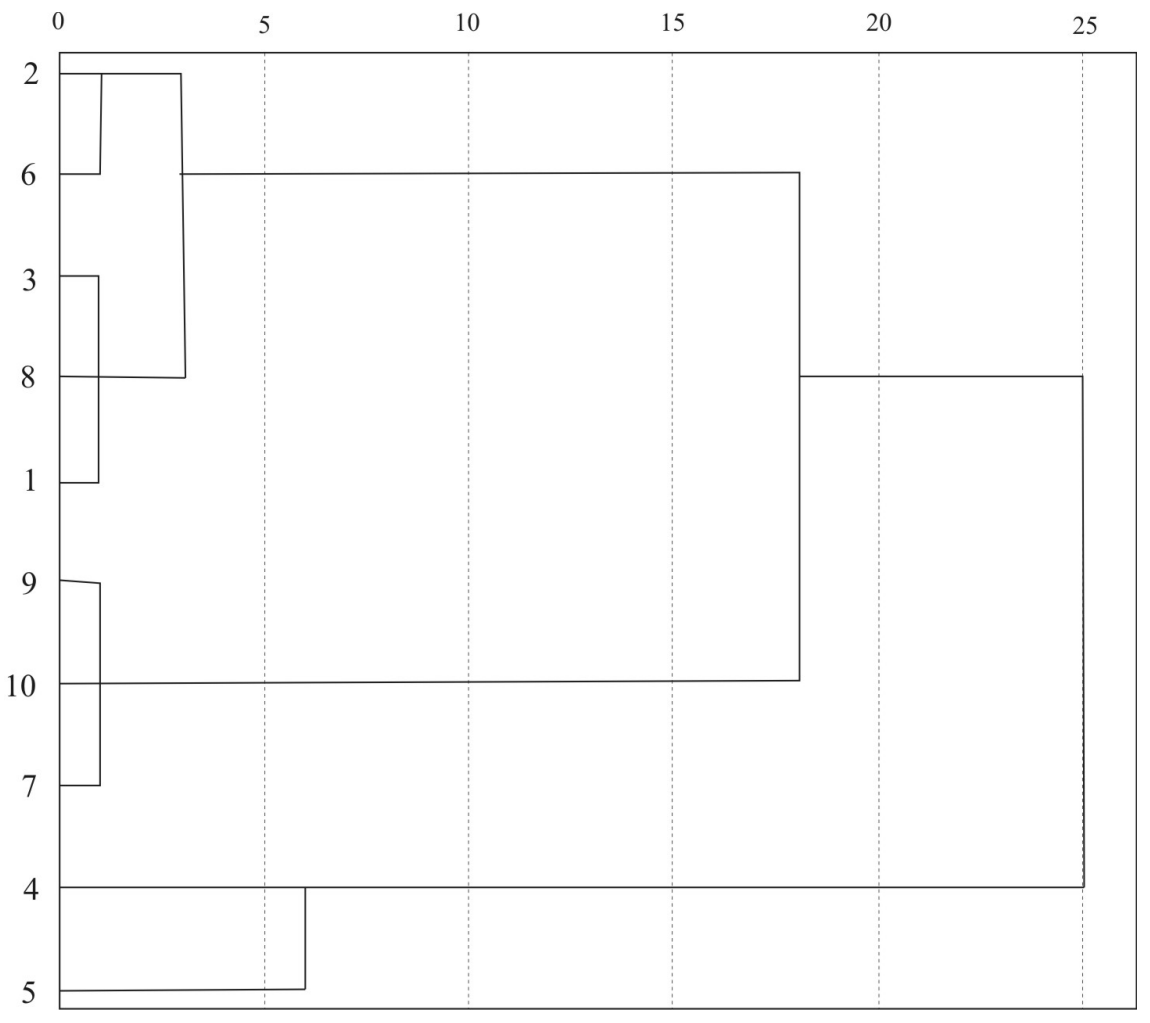

Fig. 3 Hierarchical dendrogram for investigated sites based on heavy metals' contents in raw propolis

the next abundant element and varied in content from 19.2 to $241 \mathrm{mg} / \mathrm{kg}$. Zn in propolis gathered from around Opole, Poland averaged $55.79 \mathrm{mg} /$ $\mathrm{kg}$ and in individual samples ranged from 10.91 to $115.22 \mathrm{mg} / \mathrm{kg}$ (Roman \& Pleban, 2012). The content of $\mathrm{Zn}$ in propolis samples from different regions of Turkey ranged between 176 and 676 $\mathrm{mg} / \mathrm{kg}$ (Dogan et al., 2006). Cvek et al. (2008) even determined a value of $9326 \mathrm{mg} / \mathrm{kg}$. Other investigators found $23 \mathrm{mg} / \mathrm{kg}$ (Cantarelli et al., 2011), 16.88-99.68 mg/kg (Roman, Majewska \& Pleban, 2011), 163-1364 mg/kg (Bonvehi \& Bermejo, 2013), and 17.7-71.5 mg/kg (Formicki et al., 2013). The content of Cu was quite uniform (2.22-3.9 mg/kg) except for two samples (5.0 and $8.70 \mathrm{mg} / \mathrm{kg}$ ). Other similar obtained values were 1.09-18.32 mg/kg (Roman \& Pleban, 2012), 2.08-4.72 mg/kg (Bonvehi \& Bermejo, 2013), and 1.73-9.57 mg/kg (Roman, Majewska \& Pleban, 2011). Dogan et al. (2006) determined higher Cu content of $45-96 \mathrm{mg} / \mathrm{kg}$ in propolis samples from different regions of Turkey and Roman (1997) found 23.51 to $34.15 \mathrm{mg} / \mathrm{kg}$ in samples from Glogow, Poland. Ni has been much less frequently studied and mostly in honey:
0.004-3.23 mg/kg (Porrini et al., 2002), $<0.001 \mathrm{mg} / \mathrm{kg}$ (Devillers et al., 2002a), and 0.09-0.34 $\mathrm{mg} / \mathrm{kg}$ (Devillers et al., 2002b). Its content in propolis in other studies ranged from $1.99 \mathrm{mg} /$ $\mathrm{kg}$ to $9.81 \mathrm{mg} / \mathrm{kg}$ (Formicki et al., 2013), 0.64-3.65 mg/kg (Bonvehi \& Bermejo, 2013) and $2.50 \mathrm{mg} / \mathrm{kg}$ in a dry extract of propolis and Romanian honey (Matei et al., 2004). The $\mathrm{Cr}$ and $\mathrm{Mn}$ content in the last mentioned samples were 0.80 and $6.51 \mathrm{mg} / \mathrm{kg}$, respectively. Also, Bonvehi \& Bermejo (2013) determined 6.42-27.1 $\mathrm{mg} / \mathrm{kg} \mathrm{Mn}, 4.21-14.90 \mathrm{mg} / \mathrm{kg}$ B, 479-897 mg/kg Si, 0.33-2.73 $\mathrm{mg} / \mathrm{kg} \mathrm{Cr}, 0.050-0.84 \mathrm{mg} / \mathrm{kg}$ Co and $<112 \mu \mathrm{g} / \mathrm{kg} \mathrm{Se}$. It is evident that the Serbian propolis samples contain lower amounts of Si and higher amounts of Se. There is a close correlation between the level of heavy metals accumulated in the soil and plants and their content in bee products (Kabata-Pendias, 2011). Propolis is much more contaminated by toxic elements than multi-flower honey, but both of them can be used as bioindicators to evaluate the degree of environmental pollution through the determination of the level of accumulated toxic elements (Roman, Majewska \& Pleban, 2011). Even at a low concentration, such elements may cause many diseases and abnormalities in the functioning of the human organism. As and $\mathrm{Hg}$ were not detected in all samples, but some studies showed the content of As from 0.007 to $1.806 \mathrm{mg} \mathrm{kg}^{-1}$ (Roman \& Pleban, 2012), 0.561-0.670 mg/kg (Roman, $1997)$ and $0.075-0.13 \mathrm{mg} / \mathrm{kg}$ and $8 \mu \mathrm{g} / \mathrm{kg} \mathrm{Hg}$ (Bonvehi \& Bermejo, 2013).

$\mathrm{Pb}$, one of the most widespread heavy metals in the environment, originates mainly from motor traffic and can contaminate the air and then directly nectar and honeydew. The penetration of Pb into propolis, as well as into bee bodies and beeswax poses a threat to bees and consumers. 
Operating conditions for iCAP 6000 ICP-OES

Table 1

\begin{tabular}{cc}
\hline Parameter & \\
\hline Flush Pump Rate & $100 \mathrm{rpm}$ \\
Analysis Pump Rate & $50 \mathrm{rpm}$ \\
RF Power & $1150 \mathrm{~W}$ \\
Nebulizer Gas Flow & $0.7 \mathrm{~L} / \mathrm{min}$ \\
Coolant Gas Flow & $12 \mathrm{~L} / \mathrm{min}$ \\
Auxiliary Gas Flow & $0.5 \mathrm{~L} / \mathrm{min}$ \\
Plasma View & axial \\
\hline
\end{tabular}

Table 2

Parameters of the analytical calibration curves: wavelength $\lambda(\mathrm{nm})$, limits of detection and quantification (LOD and LOQ, ppm), correlation coefficient r

\begin{tabular}{ccccc}
\hline Element & $\lambda / \mathrm{nm}$ & LOD/ppm & LOQ/ppm & $\Gamma$ \\
\hline $\mathrm{Al}$ & 396.152 & 0.001913 & 0.006378 & 0.999224 \\
$\mathrm{As}^{\star}$ & 228.812 & 0.002126 & 0.007088 & 0.999403 \\
$\mathrm{~B}$ & 249.678 & 0.001127 & 0.003757 & 0.996193 \\
$\mathrm{Ca}$ & 422.673 & 0.000729 & 0.002430 & 0.997874 \\
$\mathrm{Cd}$ & 228.802 & 0.000181 & 0.000604 & 0.999971 \\
$\mathrm{Co}$ & 237.862 & 0.001612 & 0.005372 & 0.998722 \\
$\mathrm{Cr}$ & 267.716 & 0.000678 & 0.002259 & 0.998915 \\
$\mathrm{Cu}$ & 224.700 & 0.000705 & 0.002351 & 0.999987 \\
$\mathrm{Fe}$ & 259.940 & 0.000590 & 0.001967 & 0.998907 \\
$\mathrm{Hg}$ & 184.950 & 0.017125 & 0.057083 & 0.999646 \\
$\mathrm{~K}$ & 766.490 & 0.001610 & 0.005368 & 0.995369 \\
$\mathrm{Li}$ & 670.784 & 0.000086 & 0.000287 & 0.996200 \\
$\mathrm{Mg}$ & 285.213 & 0.000247 & 0.000823 & 0.999403 \\
$\mathrm{Mn}$ & 257.610 & 0.000104 & 0.000347 & 0.998832 \\
$\mathrm{Na}$ & 588.995 & 0.000480 & 0.001600 & 0.999989 \\
$\mathrm{Ni}$ & 231.604 & 0.000472 & 0.001572 & 0.999986 \\
$\mathrm{P}$ & 213.618 & 0.004050 & 0.013501 & 0.999927 \\
$\mathrm{~Pb}$ & 220.353 & 0.002348 & 0.007826 & 0.999983 \\
$\mathrm{Se}$ & 196.090 & 0.003420 & 0.011400 & 0.999953 \\
$\mathrm{Si}$ & 212.412 & 0.001170 & 0.003901 & 0.997226 \\
$\mathrm{Sn}$ & 189.989 & 0.001084 & 0.003614 & 0.999868 \\
$\mathrm{Zn}$ & 213.856 & 0.000119 & 0.000396 & 0.999998 \\
\hline
\end{tabular}

*not detected

Pb is known not to be transported from the soil to plants (Bogdanov, 2006). A considerable amount of $\mathrm{Pb}$ was noticeable in the analyzed samples and ranged from 2.0 to $9.7 \mathrm{mg} / \mathrm{kg}$. Numerous authors have found increased concentrations of this contaminant: $0.39-18.29 \mathrm{mg} / \mathrm{kg}$ (Roman \& Pleban, 2012), $18.39 \mathrm{mg} / \mathrm{kg}$ from Glogow and $17.83 \mathrm{mg} / \mathrm{kg}$ from Rudna, Poland (Roman, 2000), 0.56-9.94 mg/kg (Roman, Majewska \& Pleban,
2011), and $0.89-2.94 \mathrm{mg} / \mathrm{kg}$ (Formicki et al., 2013). All the 25 propolis samples from southern Spain contained less than $3.80 \mathrm{mg} / \mathrm{kg}$ (Bonvehi \& Bermejo, 2013). In an analysis of bees and bee products from four regions of Poland, Majewska \& Jasinsky (2003) found that propolis was the most heavily contaminated material by $\mathrm{Pb}$ : $1.2-28.47 \mathrm{mg} / \mathrm{kg}$ in propolis, $0.114-4.76 \mathrm{mg} / \mathrm{kg}$ in the bee body, $0.01-0.069 \mathrm{mg} / \mathrm{kg}$ in the brood, 
Bee hives location, height above sea level, bees available vegetation, propolis colour

\begin{tabular}{|c|c|c|}
\hline Location & Existing vegetation (sampling season) & Colour \\
\hline 1. Rtanj Mountain & $\begin{array}{l}\text { conifers (fir and pine) } 5 \% \text {, beech } 10 \% \text {, poplar and willow } 1 \% \text {, birch } \\
2-3 \% \text {, linden } 2-3 \% \text {, hawthorn, blackthorn, pomegranate } 5 \% \text {, meadows } \\
\text { without cultivated land (summer) }\end{array}$ & light brown \\
\hline 2. Baba Mountain & $\begin{array}{l}\text { poplar and willow } \\
5 \% \text { each, all kinds of fruits including cherry plum } 5 \% \text {, conifers } 1 \% \text {, } \\
\text { acacia } 20 \% \text { and the rest is cultivated land (summer) }\end{array}$ & reddish \\
\hline $\begin{array}{l}\text { 3. Kosmaj Moun- } \\
\text { tain-Belgrade side }\end{array}$ & $\begin{array}{l}\text { acacia } 20 \% \text {, willow } 2.5 \% \text {, poplar } 2.5 \% \text {, conifers } 10 \% \text {, and the rest are } \\
\text { meadows (summer) }\end{array}$ & light brown \\
\hline 4. Tara Mountain & pine $80 \%$ (summer) & $\begin{array}{l}\text { grayish } \\
\text { brown }\end{array}$ \\
\hline 5. Niš & $\begin{array}{l}\text { fruits } 10 \% \text {, acacia } 5 \% \text {, poplar and willow } 5 \% \text {, and the rest meadows } \\
\text { (spring) }\end{array}$ & light brown \\
\hline 6. Mali Zvornik & conifers, meadow 50-50\% (autumn) & light brown \\
\hline $\begin{array}{l}\text { 7. Gledićke } \\
\text { Mountains }\end{array}$ & $\begin{array}{l}\text { willow, hazel, poplar each } 5 \% \text {, acacia } 10 \% \text {, blackberries, hawthorn, } \\
\text { blackthorn } 5 \% \text {, and the rest meadows (spring) }\end{array}$ & $\begin{array}{l}\text { grayish } \\
\text { brown }\end{array}$ \\
\hline $\begin{array}{l}\text { 8. Kosmaj } \\
\text { Mountain- } \\
\text { Lazarevac side }\end{array}$ & $\begin{array}{l}\text { all kinds of fruits } 20 \% \text {, acacia } 20 \% \text {, and the rest cultivated land and } \\
\text { meadows (summer) }\end{array}$ & light brown \\
\hline 9. Sečanj & 10\% willow and poplar, and the rest cultivated land (summer) & light brown \\
\hline 10. Kraljevo & $\begin{array}{l}\text { acacia } 20 \% \text {, willow } 5 \% \text {, poplar } 10 \% \text {, fruits } 5 \% \text {, and the rest meadows } \\
\text { (autumn) }\end{array}$ & light brown \\
\hline
\end{tabular}

The content of essential macroelements $\pm S D(\mathrm{mg} / \mathrm{kg})$ in analyzed samples of raw propolis

\begin{tabular}{cccccc}
\hline Sample & $\mathrm{Na}$ & $\mathrm{Ca}$ & $\mathrm{Mg}$ & $\mathrm{K}$ & $\mathrm{P}$ \\
\hline 1 & $256 \pm 7^{\mathrm{h}}$ & $1504 \pm 15^{\mathrm{h}}$ & $315 \pm 7^{\mathrm{f}}$ & $839 \pm 19^{\mathrm{e}}$ & $344 \pm 5^{\mathrm{e}}$ \\
2 & $128 \pm 2^{\mathrm{f}}$ & $1055 \pm 11^{\mathrm{f}}$ & $188 \pm 3^{\mathrm{c}}$ & $851 \pm 22^{\mathrm{e}}$ & $134 \pm 2^{\mathrm{a}}$ \\
3 & $225 \pm 4^{\mathrm{a}}$ & $1168 \pm 22^{\mathrm{g}}$ & $235 \pm 6^{\mathrm{d}}$ & $324 \pm 13^{\mathrm{a}}$ & $233 \pm 5^{\mathrm{c}}$ \\
4 & $63.5 \pm 0.9^{\mathrm{a}}$ & $529 \pm 9^{\mathrm{a}}$ & $139.0 \pm 0.8^{\mathrm{a}}$ & $456 \pm 6^{\mathrm{b}}$ & $241 \pm 3^{\mathrm{c}}$ \\
5 & $65.7 \pm 0.2^{\mathrm{a}}$ & $627 \pm 5^{\mathrm{b}}$ & $143.5 \pm 0.4^{\mathrm{a}}$ & $639 \pm 11^{\mathrm{c}}$ & $185 \pm 3^{\mathrm{b}}$ \\
6 & $111 \pm 3^{\mathrm{e}}$ & $648 \pm 14^{\mathrm{bc}}$ & $157 \pm 3^{\mathrm{b}}$ & $641 \pm 11^{\mathrm{c}}$ & $287 \pm 2^{\mathrm{d}}$ \\
7 & $84 \pm 4^{\mathrm{b}}$ & $1031 \pm 55^{\mathrm{d}}$ & $272 \pm 13^{\mathrm{e}}$ & $821 \pm 40^{\mathrm{e}}$ & $422 \pm 26^{\mathrm{f}}$ \\
8 & $94 \pm 3^{\mathrm{c}}$ & $666 \pm 9^{\mathrm{c}}$ & $166 \pm 4^{\mathrm{b}}$ & $711 \pm 18^{\mathrm{d}}$ & $337 \pm 8^{\mathrm{e}}$ \\
9 & $86 \pm 2^{\mathrm{bd}}$ & $837 \pm 17^{\mathrm{d}}$ & $224 \pm 6^{\mathrm{d}}$ & $1157 \pm 13^{\mathrm{g}}$ & $343 \pm 2^{\mathrm{e}}$ \\
10 & $91 \pm 2^{\mathrm{cd}}$ & $914 \pm 8^{\mathrm{e}}$ & $351 \pm 2^{\mathrm{a}}$ & $922 \pm 3^{\mathrm{f}}$ & $200 \pm 3^{\mathrm{b}}$ \\
\hline
\end{tabular}

SD-standard deviation for triplicate determination; mean values in the same column with different letters indicate significant differences ( $p<0.05)$; a is always lower than $b$ and $b$ is always lower than $c$, etc.

$0.005-0.147 \mathrm{mg} / \mathrm{kg}$ in honey, 0.041-0.447 mg/kg in bee bread and 0.054-3.18 mg/kg in beeswax. Unlike $\mathrm{Pb}, \mathrm{Cd}$ originating from metal industry and incinerators is transported from the soil to plants. Only a small portion of Cd might reach bee products by air (Bogdanov, 2006). Elevated Cd content can occur in bee products from agricultural regions where there is high consumption of mineral fertilizers and plant pesticides. Roman, Bartkowiak \& Reginia (2007) found an increased concentration level of Cd in multi-flower honey (average $0.373 \mathrm{mg} / \mathrm{kg}$ ) in the control region agricultural and forest areas, in comparison with the experimental region with copper industry (average $0.059 \mathrm{mg} / \mathrm{kg}$ ). The $\mathrm{Cd}$ concentration in the examined bee products ranged from 
Table 5

The content of essential trace elements and trace elements that are probably essential $\pm \mathrm{SD}(\mathrm{mg} / \mathrm{kg})$ in analyzed samples of raw propolis

\begin{tabular}{|c|c|c|c|c|c|c|c|c|c|c|}
\hline $\begin{array}{l}\frac{\omega}{0} \\
\text { 竞 } \\
\text { N }\end{array}$ & $\mathrm{Fe}$ & Zn & $\mathrm{Cu}$ & B & Co & $\mathrm{Si}$ & Mn & $\mathrm{Ni}$ & $\mathrm{Cr}$ & Se \\
\hline 1 & $198 \pm 4^{d}$ & $51.9 \pm 0.8^{f}$ & $8.70 \pm 0.03^{9}$ & $39.9 \pm 0.8^{h}$ & $0.77 \pm 0.05^{f}$ & $117 \pm 2^{h}$ & $12.0 \pm 0.3^{f}$ & $1.55 \pm 0.04^{h}$ & $9.9 \pm 0.2^{h}$ & $5.4 \pm 0.3^{f}$ \\
\hline 2 & $116 \pm 3^{a}$ & $24.5 \pm 0.3^{b}$ & $3.24 \pm 0.05^{c}$ & $15.1 \pm 0.1^{d}$ & $0.56 \pm 0.02^{d}$ & $24.3 \pm 0.2^{9}$ & $3.98 \pm 0.09^{a}$ & $0.98 \pm 0.02^{d}$ & $0.99 \pm 0.02^{b}$ & $4.78 \pm 0.04^{e}$ \\
\hline 3 & $158 \pm 5^{b}$ & $21.0 \pm 0.3^{a}$ & $5.00 \pm 0.03^{f}$ & $29 \pm 1^{9}$ & $0.42 \pm 0.02^{b}$ & $7.6 \pm 0.2^{c}$ & $8.4 \pm 0.3^{e}$ & $1.07 \pm 0.03^{e}$ & $3.4 \pm 0.2^{f}$ & $4.6 \pm 0.4^{e}$ \\
\hline 4 & $208 \pm 1^{d}$ & $241 \pm 3^{i}$ & $3.02 \pm 0.04^{b}$ & $8.54 \pm 0.03^{a}$ & $1.90 \pm 0.03$ & $7.29 \pm 0.06^{c}$ & $14.36 \pm 0.08^{9}$ & $1.46 \pm 0.02^{g}$ & $1.94 \pm 0.02^{d}$ & $3.02 \pm 0.08^{b}$ \\
\hline 5 & $123 \pm 2^{a}$ & $145 \pm 2^{h}$ & $2.22 \pm 0.05^{\mathrm{a}}$ & $8.5 \pm 0.2^{\mathrm{a}}$ & $0.51 \pm 0.01^{c}$ & $3.68 \pm 0.04^{\mathrm{a}}$ & $6.14 \pm 0.05^{b}$ & $0.50 \pm 0.01^{a}$ & $0.71 \pm 0.02^{\mathrm{a}}$ & $3.19 \pm 0.03^{b c}$ \\
\hline 6 & $127 \pm 3^{a}$ & $19.2 \pm 0.2^{a}$ & $2.86 \pm 0.07^{b}$ & $14.8 \pm 0.3^{d}$ & $0.30 \pm 0.03^{a}$ & $13.2 \pm 0.1^{e}$ & $7.7 \pm 0.2^{d}$ & $1.21 \pm 0.03^{f}$ & $1.10 \pm 0.03^{b}$ & $3.4 \pm 0.2^{\mathrm{cd}}$ \\
\hline 7 & $284 \pm 23^{f}$ & $75.1 \pm 0.8^{9}$ & $3.40 \pm 0.02^{\mathrm{cd}}$ & $19 \pm 2^{\dagger}$ & $0.94 \pm 0.03^{\mathrm{h}}$ & $4.9 \pm 0.3^{b}$ & $7.7 \pm 0.7^{d}$ & $0.69 \pm 0.01^{c}$ & $1.38 \pm 0.03^{c}$ & $2.7 \pm 0.2^{\mathrm{a}}$ \\
\hline 8 & $173 \pm 4^{c}$ & $32.8 \pm 0.8^{d}$ & $2.90 \pm 0.08^{b}$ & $13.9 \pm 0.3^{c}$ & $0.64 \pm 0.03^{e}$ & $10.2 \pm 0.2^{d}$ & $6.1 \pm 0.2^{b}$ & $0.58 \pm 0.02^{b}$ & $2.39 \pm 0.08$ & $2.96 \pm 0.01^{\mathrm{b}}$ \\
\hline 9 & $263 \pm 8^{e}$ & $42.5 \pm 0.2^{\mathrm{e}}$ & $3.52 \pm 0.06^{d}$ & $11.7 \pm 0.3^{b}$ & $0.82 \pm 0.069$ & $21.63 \pm 0.05^{\dagger}$ & $7.0 \pm 0.3^{c}$ & $0.50 \pm 0.02^{\mathrm{a}}$ & $0.73 \pm 0.02^{\mathrm{a}}$ & $3.47 \pm 0.09^{d}$ \\
\hline 10 & $283 \pm 2^{\dagger}$ & $29.6 \pm 0.5^{c}$ & $3.9 \pm 0.1^{e}$ & $17.7 \pm 0.2^{e}$ & $0.90 \pm 0.04^{\mathrm{h}}$ & $12.7 \pm 0.3^{e}$ & $7.7 \pm 0.2^{d}$ & $1.59 \pm 0.04^{i}$ & $4.17 \pm 0.05^{9}$ & $3.59 \pm 0.04^{d}$ \\
\hline
\end{tabular}

SD-standard deviation for triplicate determination; mean values in the same column with different letters indicate significant differences ( $p<0.05)$; $a$ is always lower than $b$ and $b$ is always lower than $c$, etc.

Table 6

The content of potentially toxic and toxic elements $\pm \mathrm{SD}(\mathrm{mg} / \mathrm{kg})$ in analyzed samples of raw propolis

\begin{tabular}{cccccc}
\hline Sample & $\mathrm{Cd}$ & $\mathrm{Pb}$ & $\mathrm{Al}$ & $\mathrm{Li}$ & $\mathrm{Sn}$ \\
\hline 1 & $0.31 \pm 0.01^{\mathrm{i}}$ & $9.7 \pm 0.6^{\mathrm{i}}$ & $139 \pm 3^{\mathrm{e}}$ & $0.14 \pm 0.01^{\mathrm{d}}$ & $3.3 \pm 0.2^{\mathrm{f}}$ \\
2 & $0.150 \pm 0.004^{\mathrm{e}}$ & $5.11 \pm 0.08^{\mathrm{e}}$ & $70 \pm 2^{\mathrm{b}}$ & $0.087 \pm 0.004^{\mathrm{b}}$ & $1.36 \pm 0.02^{\mathrm{d}}$ \\
3 & $0.12 \pm 0.01^{\mathrm{d}}$ & $2.0 \pm 0.3^{\mathrm{a}}$ & $138 \pm 5^{\mathrm{e}}$ & $0.077 \pm 0.002^{\mathrm{a}}$ & $1.32 \pm 0.03^{\mathrm{d}}$ \\
4 & $0.067 \pm 0.003^{\mathrm{a}}$ & $7.7 \pm 0.2^{\mathrm{g}}$ & $60 \pm 1^{\mathrm{a}}$ & $0.070 \pm 0.003^{\mathrm{a}}$ & $1.37 \pm 0.03^{\mathrm{d}}$ \\
5 & $0.283 \pm 0.005^{\mathrm{h}}$ & $3.60 \pm 0.04^{\mathrm{c}}$ & $75.0 \pm 0.5^{\mathrm{b}}$ & $0.078 \pm 0.003^{\mathrm{ab}}$ & $0.98 \pm 0.02^{\mathrm{ab}}$ \\
6 & $0.166 \pm 0.005^{\dagger}$ & $2.5 \pm 0.1^{\mathrm{b}}$ & $76 \pm 1^{\mathrm{b}}$ & $0.098 \pm 0.005^{\mathrm{c}}$ & $1.09 \pm 0.02^{\mathrm{bc}}$ \\
7 & $0.080 \pm 0.005^{\mathrm{b}}$ & $6.17 \pm 0.03^{\mathrm{f}}$ & $158 \pm 11^{\dagger}$ & $0.16 \pm 0.02^{\mathrm{e}}$ & $2.9 \pm 0.2^{\mathrm{e}}$ \\
8 & $0.110 \pm 0.005^{\mathrm{cd}}$ & $4.0 \pm 0.2^{\mathrm{d}}$ & $112 \pm 3^{\mathrm{d}}$ & $0.13 \pm 0.03^{\mathrm{d}}$ & $0.93 \pm 0.03^{\mathrm{a}}$ \\
9 & $0.109 \pm 0.003^{\mathrm{c}}$ & $2.67 \pm 0.06^{\mathrm{b}}$ & $159 \pm 4^{\dagger}$ & $0.211 \pm 0.005^{\dagger}$ & $1.12 \pm 0.02^{\mathrm{c}}$ \\
10 & $0.222 \pm 0.003^{\mathrm{g}}$ & $8.6 \pm 0.4^{\mathrm{h}}$ & $103 \pm 2^{\mathrm{c}}$ & $0.139 \pm 0.003^{\mathrm{d}}$ & $7.0 \pm 0.1^{\mathrm{g}}$ \\
\hline
\end{tabular}

SD-standard deviation for triplicate determination; mean values in the same column with different letters indicate significant differences ( $p<0.05)$; $a$ is always lower than $b$ and $b$ is always lower than $c$, etc.

0.067 to $0.31 \mathrm{mg} / \mathrm{kg}$, which is in accordance with other studies of propolis originating from the region of copper industry. Roman, Majewska \& Pleban (2011) found 0.069-0.802 mg/kg, Roman \& Pleban (2012) found 0.006-0.811 mg/ $\mathrm{kg}$ and Roman (1997) found 0.043-0.116 mg/ $\mathrm{kg}$. Propolis was found to be more contaminated with $C d$ in the region with a large cement industry. Roman (1997) discovered 0.513-0.795 $\mathrm{mg} / \mathrm{kg}$ and Formicki et al. (2013) 0.0125-0.0496 $\mathrm{mg} / \mathrm{kg}$. Arslan \& Arikan (2013) investigated the content of $\mathrm{Cu}, \mathrm{Cd}, \mathrm{Zn}, \mathrm{Fe}, \mathrm{Cr}, \mathrm{Pb}$ and $\mathrm{Mn}$ in honey, pollen and propolis samples from nine stations which were at various distances from a highway and discovered that the most Cd was accumulated at its edge. Al was present in the range of $60-159 \mathrm{mg} / \mathrm{kg}$, which was less than the results of Bonvehi \& Bermejo (2013) who considered the concentration of $308-582 \mathrm{mg} /$ $\mathrm{kg}$ as naturally high and characteristic of mineral-rich acidic soil. In the same samples, Sn was present in an amount of less than $112 \mu \mathrm{g} / \mathrm{kg}$. Based on the results of the Tukey's post-hoc test shown in the tables with metal contents, the tested samples from various locations differed mainly in the content of metals Zn, Cd, 
The values of correlation coefficient $r$ between investigated heavy metals

\begin{tabular}{ccccccccc}
\hline Metal & $\mathrm{Fe}$ & $\mathrm{Zn}$ & $\mathrm{Cu}$ & $\mathrm{Cd}$ & $\mathrm{Co}$ & $\mathrm{Cr}$ & $\mathrm{Ni}$ & $\mathrm{Pb}$ \\
\hline $\mathrm{Fe}$ & 1 & 0.034 & 0.145 & -0.239 & 0.487 & 0.157 & 0.111 & 0.443 \\
$\mathrm{Zn}$ & & 1 & -0.244 & -0.128 & $0.777^{* *}$ & -0.159 & 0.080 & 0.288 \\
$\mathrm{Cu}$ & & & 1 & 0.474 & -0.039 & $0.944^{* *}$ & 0.516 & 0.509 \\
$\mathrm{Cd}$ & & & & 1 & -0.372 & 0.568 & 0.259 & 0.331 \\
$\mathrm{Co}$ & & & & & 1 & 0.039 & 0.336 & 0.573 \\
$\mathrm{Cr}$ & & & & & & 1 & 0.621 & $0.656^{\star}$ \\
$\mathrm{Ni}$ & & & & & & & 1 & $0.670^{*}$ \\
$\mathrm{~Pb}$ & & & & & & & & 1 \\
\hline
\end{tabular}

** correlation is significant at the 0.01 level

* correlation is significant at the 0.05 level

$\mathrm{Co}, \mathrm{Ni}, \mathrm{Cr}$ and $\mathrm{Pb}$. These metals are predominantIy those which contaminate bee products, either from the environment or during production and storage.

Dietetic Product Safety Regulation prescribes the maximum allowable amount of $\mathrm{Pb}, \mathrm{Cd}$ and $\mathrm{Hg}$ in dietary supplements to be 3,1 and $0.1 \mathrm{mg} / \mathrm{kg}$, respectively (Official Gazette of the Republic of Serbia, No. 45 (2010), 27 (2011) and 50 (2012)). The same values are prescribed by the European Commission which set maximum levels for certain contaminants in foodstuffs (Commission Regulation, 2006). Tab. 7 demonstrates that a good correlation exists between the following couples of elements: $\mathrm{Zn}-\mathrm{Co}$; $\mathrm{Cu}-\mathrm{Cr}$; $\mathrm{Cr}$-Pb and $\mathrm{Ni}-\mathrm{Pb}$, and strong interdependence suggests a common source of both metals. Based on the other correlations, it can be concluded that a good correlation exists between elements which are naturally present in the soil i.e. alkali and alkaline earth metals, iron, silicon and aluminium. Because $\mathrm{Cu}$ and $\mathrm{Cr}$ also correlate well with these elements, they are assumed to be of the same geological and botanical origin. Cd does not correlate with any element, Zn correlates only with $\mathrm{Co}$, and $\mathrm{Ni}$ only with $\mathrm{Pb}$, and they are assumed to be of dominantly anthropogenic origin, especially $\mathrm{Pb}$. The cluster analysis of the samples (Fig. 2) based on the content of all the investigated metals shows the existence of tree clusters which include quite distant areas except for places 7 and 10, Gledićke Mountains and Kraljevo, respectively. This confirms that the composition of elements in propolis as bee product is influenced by the geographical origin of the elements, botanical origin of bee products, weather and season, vicinity of roads and industrial plants and bee-keeping methods. A cluster analysis of the samples (Fig. 3 ), based on the content of heavy metals, shows existence of tree clusters with a different distribution of locations compared to the cluster analysis of all the elements. Only two territorially close locations 3 and 8, Kosmaj Mountain (Belgrade side) and Kosmaj Mountain (Lazarevac side) respectively, belong to the same cluster. Based on the presented results, macroelements are the most common elements, with the greatest content of $\mathrm{Ca}$ and the lowest of $\mathrm{Na}$, which was also the case in most other studies. Among the studied essential trace elements, $\mathrm{Fe}$ is the most common element, followed by $\mathrm{Zn}$, which has the most varied content. The results of the Tukey's post-hoc test show that the tested samples from various locations differ mainly in the content of $\mathrm{Zn}, \mathrm{Cd}, \mathrm{Co}, \mathrm{Ni}, \mathrm{Cr}$ and $\mathrm{Pb}$. These metals can mainly contaminate bee products either through the environment or during production and storage. As and $\mathrm{Hg}$ were not detected in any of the samples while there were considerable $\mathrm{Pb}$ and $\mathrm{Cd}$ amounts in the analyzed samples, with some value even above what is prescribed by national and international regulations. Because honeybees may forage over several kilometres from their hives, they effectively sample the environment for contaminants and locations from rural areas could have some amounts of heavy metals originat- 


\section{TDSRE ET HL.}

ing from highways with intense traffic. Thus, only selected portions of previously analyzed raw propolis can be used to produce natural medicines and dietary supplements for humans. Differences in the contents of individual elements also exist in the case of other studies. The soil type and parameters, mobility of metals, botanical origin of samples and weather conditions can cause the obtained differences in the mineral profile of investigated propolis from different locations. These facts are reflected in the grouping of some distant locations in the same cluster or subcluster.

The results of the Pearson's correlation study show that $\mathrm{Cu}$ and $\mathrm{Cr}$ correlate well with the elements that are otherwise naturally present in soils. Because of that it can be assumed that they are of geological and botanical origin unlike Cd which does not correlate with any element, and $\mathrm{Zn}$ which correlates only with $\mathrm{Co}$, and $\mathrm{Ni}$ only with $\mathrm{Pb}$. These elements are probably of dominant anthropogenic origin, especially $\mathrm{Pb}$.

\section{ACKNOWLEDGEMENT}

This research was supported by grant numbers 172047 and 1612033 of the Ministry of Education, Science and Technological Development of Serbia. The authors are grateful for the financial support provided by this Ministry.

\section{REFERENCES}

Arslan, S. \& Arikan, A. (2013). Accumulation of Heavy Metals in Bee Products. Effect of Distance from Highway. Turkish Journal of Agriculture-Food Science and Technology, 7(2), 90-93.

Bogdanov, S. (2006). Contaminants of bee products. Apidologie, 371), 1-18. http://dx.doi.org/10.1051/apido:2005043

Bogdanov, S. (2014). Propolis: Composition, Health, Medicine: A Review. Bee Product Science, 1-40. http://www.bee-hexagon.net/files/file/fileE/ Health/PropolisBookReview.pdf

Bonvehi, J. \& Bermejo, F. J. (2013). Element content

\section{Minerals in propolis}

of propolis collected from different areas of South Spain. Environmental Monitoring and Assessment, 185(7), 6035-6047.

Cantarelli, M. A., Camina, J. M., Pettenati, E. M., Marchevsky, E. J. \& Pellerano, R. G. (2011). Trace mineral content of Argentinean raw propolis by neutron activation analysis (NAA): Assessment of geographical provenance by chemometrics. Food Science and Technology, 44,256-260. http://dx.doi.org/10.1016/j. Iwt.2010.06.031

Commission Regulation 2006/1881/EC of 19 December 2006 setting maximum levels for certain contaminats in foodstuffs. (2006). Official Journal of the European Communities L, 364, 5.

Conti, M. E. \& Botre, F. (2001). Honey bees and their products as potential bioindicators of heavy metals contamination. Environmental Monitoring and Assessment, 69(3), 267-282. http://dx.doi. org/10.1023/A:1010719107006

Cunha, I. B. S., Bueno, M. I. M. S., Marcucci, M. C. \& Custódio, A. R. (1997). Characterization of Brazilian propolis by $\mathrm{X}$-ray fluorescence: contamination by lead evidence. Lecta, 15, 99-104.

Cvek, J., Medić-Šarić, M., Witali, D., Vedrina-Dragojević, I., Smit, Z. \& Tomić, S. J. (2008). The content of essential and toxic elements in Croatian propolis samples and their tinctures. Journal of Apicultural Research, 47,35-45. http://dx.doi.org/10.1080/00218839.20 08.11101421

Devillers, 」., Dore, J. C., Viel, C., Marenco, M., PoirierDuchene, F., Galand, N. \& Subirana, M. (2002a). Typology of French acacia honeys based on their concentrations in metallic and nonmetallic elements. In Honey bees: Estimating the environmental impact of chemicals. (pp. 248-268). London and New York: Taylor and Francis.

Devillers, J., Dore, J. C., Marenco, M., Poirier-Duchene, F., Galand, N. \& Viel, C. J. (2002b). Chemometrical Analysis of 18 Metallic and Nonmetallic Elements Found in Honeys Sold in France. Journal of Agricultural and Food Chemistry, 50, 5998-6007. D0l: 10.1021/ 
jf020497r

Dogan, M., Silici, S., Saraymen, R. \& Ilhan, I. O. (2006). Element content of propolis from different regions of Turkey. Acta Alimentaria, 35, 127-130. http:// dx.doi.org/ 10.1556/AAlim.35.2006.1.14

Formicki, G., Gren, A., Stawarz, R., Zysk, B. \& Gal, A. (2013). Metal Content in Honey, Propolis, Wax, and Bee Pollen and Implications for Metal Pollution Monitoring. Polish Journal of Environmental Studies, 22(1), 99-106.

Kabata-Pendias, A. (2011). Trace elements in soils and plant. London and New York: Taylor and Francis.

Korn, M. G. A., Morte, E. S. B., dos Santos, D. C. M. B., Castro, J. T., Barbosa, J. T. P., Teixeira, A. P., Fernandes, A. P., Welz, B., dos Santos W. P. C., dos Santos E. B. G. N. \& Korn M. (2008). Sample preparation for the determination of metals in food samples using spectroanalytical methods-a review. Applied Spectroscopy Reviews, 43(2), 67-92.

\section{http://dx.doi.org/10.1080/05704920701723980}

Leita, L., Muhlbachova, G., Cesco, S., Barbattini, R. \& Mondini, C. (1996). Investigation of the use of honey bees and honey bee products to assess heavy metals contamination. Environmental Monitoring and Assesment, 43(1), 1-9. http://doi.org/ 10.1007/ BF00399566

Majewska, B. M. \& Jasinski, Z. J. (2003). Lead content of bees, brood and bee products from different regions of Poland. Journal of Apicultural Science, 472), 47-55.

Matei, N., Birghila, S., Dobrinas, S. \& Capota, P. (2004). Determination of C vitamin and some essential trace elements ( $\mathrm{Ni}, \mathrm{Mn}, \mathrm{Fe}, \mathrm{Cr}$ ) in bee products. Acta Chimica Slovenica, 5, 169-175.

Official Gazette of the Republic of Serbia, No. 45 (2010), 27 (2011) and 50 (2012). Dietetic Product Safety Regulation.

Porrini, C., Ghini, S., Girotti, S., Sabatini, A. G., Gat- tavecchia, E., Celli, G. (2002). Use of honey bees as bioindicator of environmental pollution in Italy. In Honey bees: Estimating the environmental impact of chemicals. (pp. 186-247). London and New York: Taylor and Francis.

Roman, A. (1997). Pszczoly i produkty pszczele jako bioindykatory skazenia srodowiska w rejonie oddzialywania przemyslu miedziowego (LGOM) i cementowo-wapienniczego (Opole). Zeszyty Naukowe Akademii Rolniczej we Wroclawiu, Zootechnika, 323, 175-193.

Roman, A. (2000). The study comparative contents $\mathrm{Cd}, \mathrm{Pb}$ and $\mathrm{Z} \mathrm{n}$ in honey, propolis and wax come from regions of Walbrzych and Glogow. Apicultural Scientific Exercise Books, 1, 76-77.

Roman, A. \& Pleban, E. P. (2012). Contamination of propolis used as a dietary supplement. Potravinarstvo, 6(2), 50-52. http://doi.org/ 10.5219/184

Roman, A., Bartkowiak, A. \& Reginia, M. (2007). The cumulation of selected elements of toxic properties in bee honey originating from the industrial and rural-forest areas. In Proceeding of the XIII International Congress in animal hygiene (p. 877). Tartu Estonia.

Roman, A., Majewska, B. M. \& Pleban, E. P. J. (2011). Comparative study of selected toxic elements in propolis and honey. Journal of Apicultural Science, 55(2), 97-106.

Sawaya, A. C. H. F., Cunha, I. B. S. \& Marcucci, M. C. (2011). Analytical methods applied to diverse types of Brazilian propolis. Chemistry Central Journal, 5, 27. http://doi.org/ 10.1186/1752-153X-5-27

Tosi, E. A., Re, E., Ortega, M. E. \& Cazzoli, A. F. (2007). Food preservative based on propolis: bacteriostatic activity of propolis polyphenols and flavonoids upon Escherichia coli. Food Chemistry, 104, 1025-1029. http://doi.org/ 10.1016/j.foodchem.2007.01.011

World Health Organisation (1996). Trace Elements in Human Nutrition and Health, Geneva. 